\title{
UDC 628.35
}

\section{A. Y. OLEYNIK ${ }^{1}$, T. S. AIRAPETIAN ${ }^{2 *}$, S. M. KURGANSKA ${ }^{3}$}

${ }^{1}$ Institute of Hydromechanics of the NAS of Ukraine, Zheliabov St., 8/4, Kyiv, Ukraine, 03057, tel. +38 (050) 5597289 , +38 (044) 45965 10, e-mail Oleynik2019A1@gmail.com, ORCID 0000-0002-9110-1709

${ }^{2 *}$ Dep. «Water Supply, Sewerage and Purification of Waters», O. M. Beketov National University of Urban Economy in Kharkiv, Marshal Bazhanov St., 17, Kharkiv, Ukraine, 61002, tel. +38 (057) 70733 40, +38 (057) 70731 06,

e-mail Tamara.Ayrapetyan@kname.edu.ua, ORCID 0000-0002-8834-5622

${ }^{3}$ Institute of Hydromechanics of the NAS of Ukraine, Zheliabov St., 8/4, Kyiv, Ukraine, 03057, tel. +38 (063) 9178784 , e-mail kurganska@ukr.net, ORCID 0000-0002-7593-6458

\section{EVALUATION OF THE PERFORMANCE OF AEROTANKS DUE TO ADD-ON ATTACHED BIOCENOSIS}

Purpose. The research involves the implementation of comparative calculations to evaluate the performance of aerotanks with add-on attached biocenosis (biofilm). Methodology. For improving the performance of the aerotanks due to the introduction of an additional load with attached biocenosis (biofilm), the authors constructed the mathematical models that consider the simultaneous oxidation of organic pollutants with suspended and attached biocenosis. Based on these models, the methods were developed for calculating clarification parameters. The authors performed evaluation of the influence of various clarification factors in aerotanks. They proved that the clarification intensity is increased due to additional elements with the attached biocenosis. Herewith, possible technological and structural schemes of aerotanks were considered, when the loading elements (nozzles, screens, etc.) are located throughout the whole volume or more densely and compactly only in its individual sections. Findings. The parameters of effluent clarification from organic pollution in the aerotanks are determined using numerical methods. The graphs show the significant performance of aerotanks due to the introduction of the additional load with the attached biocenosis (biofilm). The calculations of the effect of additional loading on the performance of complete-mix aerotanks and continuous-flow aerotanks show that the use of immobilized biocenosis can improve the quality of removal of organic pollutants by 2-5 times. Originality. The authors substantiated scientifically the influence of various factors of wastewater treatment in aerotanks, the efficiency of which is increased due to additional elements with the attached biocenosis. Practical value. The introduction of research results in wastewater treatment plants can significantly improve the quality of the removal of organic pollutants by biological methods. The implementation of the calculation methods for the proposed dependencies makes it possible to more fully and reasonably take into account important processes that significantly affect the utilization of organic pollutants and the efficiency of the aerotanks with the additional involvement of wastewater treatment by the attached biocenosis.

Keywords: aerotanks-reactors; attached biocenosis (biomass); biofilm, active sludge; clarification reactions

\section{Introduction}

Among the most important environmental problems of the present day, the issue of protecting natural sources of water supply is of paramount importance. The discharging of raw and insufficiently treated wastewater in the surface water reservoirs constantly worsens their condition; these sources of pollution, as a rule, contain compounds of nitrogen and phosphorus. Therefore, deep purification of wastewater is one of the most important problems for today.

The accumulated experience and scientific research of many generations of specialists prove the priority of biological methods of purification. Today, the majority of wastewater, which is discharged in a centralized way, is cleared at aeration stations in aerotanks $[1,2,4,5,12]$. However, the existing conventional biological purification technology is characterized by inadequate efficiency (especially for the removal of phosphorus compounds) and is not always able to meet the set norms $[3,7,14,16,19,23]$.

Therefore, in wastewater treatment plants, where biological treatment of effluent is carried out according to the traditional scheme, the important practical tasks are the issues of improvement of existing technologies of wastewater treatment on the basis of these structures, increase of their efficiency.

In general, the following solutions are used to improve the efficiency of aerotanks: the creation of sites with aerobic and anaerobic conditions of oxi- 
dation $[2,13,21]$, the use of uneven dispersed effluent intake [2], the supply of technical oxygen [2, 15], the addition of reagent preparations [2, 15], etc. It is clear that the improvement of structures and technologies is delayed by economic factors. Also currently, the widely used effluent clarification method has become the process of simultaneous removal of organic pollutants (OP) and nitrogen by suspended and attached biocenosis [20, 22] By their activity immobilized biocenosis considerably exceed the oxidation capacity of suspended active sludge.

In this case, the loading elements (nozzles, screens, etc.) can be located throughout the volume of the aerotanks or more densely and compactly only in its individual sections.

However, the possibility of evaluating the efficiency of aerotank due to add-on elements with attached biocenosis (biofilm) requires more complete and advanced mathematical models. Models that will take into account the processes of simultaneous oxidation of OP by suspended and attached biocenosis will allow to reasonably estimate the influence of various factors of purification in aerotanks. These processes are associated with the formation of a biofilm of different thickness and structure on the surface of the additional loading (screen) in the aerotank volume [13, 21].

The parameters of wastewater treatment, determined by numerical methods, taking into account the influence of various purification factors will give an opportunity to obtain reliable results. Based on the results obtained, it is possible to evaluate the effectiveness of the aerotanks through the introduction of additional elements with the attached biocenosis (biofilm).

\section{Purpose}

The main purpose is to carry out calculations and obtain a comparative assessment of the efficiency of complete-mix aerotanks and continuousflow aeration tanks. Herewith wastewater is treated due to the additional arrangement in their volume of loading with the attached biocenosis (biomass) in the form of a biofilm with a high concentration of microorganisms.

To achieve this purpose, the following tasks need to be addressed:

- Provide calculation dependencies and mathematical models that allow estimating the influence Creative Commons Attribution 4.0 International doi: https://doi.org/10.15802/stp2019/175883 of various factors on the simultaneous removal of organic pollutants (OP) with suspended and attached biocenosis in aerotanks of various structures, namely in complete-mix aerotanks and continuous-flow aeration tanks;

- On the basis of the proposed models and methods of calculation, to conduct an analysis and evaluation of the influence of the main factors, to identify the parameters of supply of the required amount of oxygen to the place of reaction and the disposal of OP;

- To consider the specific examples for different process flow schemes of the location of the attached biomass reactor and to provide comparative results of studies of simultaneous OP purification;

- To substantiate the increased efficiency of effluent clarification due to the arrangement of the attached biocenosis in the volume of the aerotanks.

\section{Methodology}

Mathematical models were constructed and methods for calculating the parameters of purification $[6,7,11,17,18]$ were developed for the estimation and analysis of the simultaneous removal of organic pollutants (OP) with suspended and attached biocenosis in aerotanks of various structures. In this case, for various hydrodynamic schemes of aerotanks, namely complete-mix aerotanks and continuous-flow aeration tanks. The specific examples showed and substantiated a significant increase in the efficiency of purification due to the add-on attached biocenosis.

First, let us consider the most advisable from the practical point of view technological scheme of a complete-mix aerotank, which consists of two parts (reactors 1 and 2) [7]. In reactor 1, the OP is removed only due to the suspended biocenosis (active sludge), that is, it works as an ordinary complete-mix aerotank. In the second part (reactor 2), the OP removal occurs mainly by the attached biocenosis, which is formed at the add-on load, with the possible consideration, if necessary, of the action of the active sludge in the reactor 2 . It is believed that the biochemical oxidation process is adequately provided with oxygen, that is, the flow of oxygen will not limit the kinetics of oxidation of both the suspended and attached biocenosis. Let us consider also the most widespread case in which the removal of OP by an active sludge occurs by (C) O. Y. Oleynik, T. S. Airapetian, S. M. Kurganska, 2019 
a zero-order reaction, and in a biofilm - by the first-order reaction. Then, according to [7], to determine the concentration of OP at the output from the 2 nd reactor (of the aerotank) $L_{a 2}$, the following general dependence is proposed

$$
L_{a_{2}}=\frac{L_{0}-T_{a_{1}} w_{a_{1}}-T_{a_{2}} w_{a_{2}}}{1+\frac{F_{a_{2}}}{Q_{a}} K_{L}(1-A)},
$$

where

$$
\begin{array}{cc}
w_{a}=\frac{\mu_{m a} X_{a}}{Y_{a}}, & T_{a_{1}}=\frac{W_{a_{1}}}{Q_{a}}, \\
T_{a_{2}}=\frac{W_{p_{2}}}{Q_{a}}=\frac{\varepsilon W_{a_{2}}}{Q_{a}}, & T_{a}=T_{a_{1}}+T_{a_{2}} .
\end{array}
$$

For the 1st reactor, the volume of the liquid is assumed to be equal to the reactor volume $W_{\mathrm{p}_{1}}=W_{a_{1}}$. For reactor 2 it is necessary to take into account the volume loaded with biofilm $W_{\delta_{2}}$, therefore we have

$$
W_{p_{2}}=\varepsilon W_{a_{2}}, \quad \varepsilon=1-\frac{W_{\delta_{2}}}{W_{a_{2}}} .
$$

The specific loading area with the biofilm in the reactor 2 is determined by the formula

$$
F_{\delta_{n 2}}=\frac{F_{\delta_{2}}}{W_{a_{2}}}
$$

where $F_{\delta 2}$ is the total surface area of loading (biofilm) in reactor 2 of volume $W_{a 2}$.

Recommendations for determining the parameter $A=\frac{L_{\delta_{2}}}{L_{a_{2}}}$ under the assumption that the reaction rate in the biofilm is taken of the first order, are given in the papers [7,9]. Here $L_{a_{2}}$ and $L_{\delta 2}$ are the concentrations of OP in the reactor 2 and on the surface of the biofilm.

For further analysis, the dependence is represented in the form

$$
\frac{L_{a_{2}}}{L_{0}}=\frac{1-\tau}{1+\gamma}
$$

where

$$
\tau=\frac{T_{a} w_{a}}{L_{0}}, \quad \gamma=\frac{F_{a_{2}}}{Q} K_{L}(1-A) .
$$

Fig. 1 shows the graphs of the function $\frac{L_{a 2}}{L_{0}}=f(\tau, \gamma)$, constructed according to the dependence (5). It is assumed that the volumes of the first and second reactors coincide $W_{a 1}=W_{a 2}$ and that $w_{a_{1}} \approx w_{a_{2}}=w_{a}$. The results presented in Fig. 1 show that post-treatment by the attached biomass can significantly improve the quality of wastewater treatment. However, as shown by Fig. 2, with the increase of the parameter $\gamma$, which depends on the flow $\mathrm{N}$ and mainly on the specific loading area $F_{\delta n}$, that is, on the load element density, this improvement is significantly slowed down. Therefore, in this case, as in other process flow schemes of aerotanks with attached biocenosis, an important issue is the choice of the most appropriate loading area $F_{\delta}$ based on the additional analysis.

Fig. 3 shows the graphs of the function $\frac{L_{a_{2}}}{L_{0}}=f(\tau, \gamma)$, constructed under the condition that the clarification in the second reactor due to the suspended biocenosis (active sludge) can be neglected, i.e. $T_{a_{2}}=0 \quad\left(\tau=T_{a_{1}}\right)$.

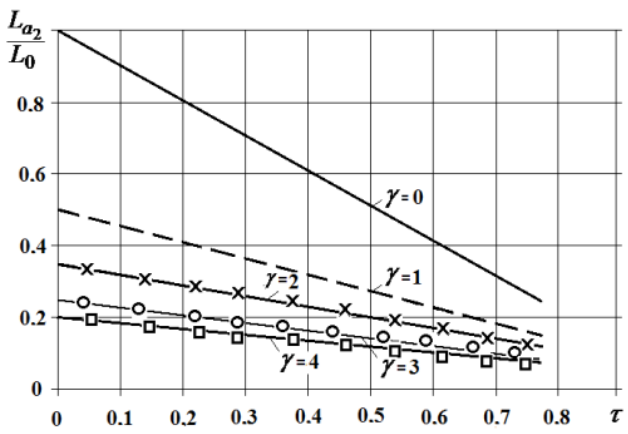

Fig. 1 Dependency graph $\frac{L_{a_{2}}}{L_{0}}=f(\tau, \gamma)$

As can be seen from the data in Fig. 1 and Fig. 3 the active sludge in the second reactor with the same values of the parameter $\tau$ does not significantly affect the overall clarification effect. However, clarification in the free volume of the 2 nd reactor allows for some increase in the value of the 
parameter $\tau$, and, accordingly, the quality of the removal of organic pollutants.

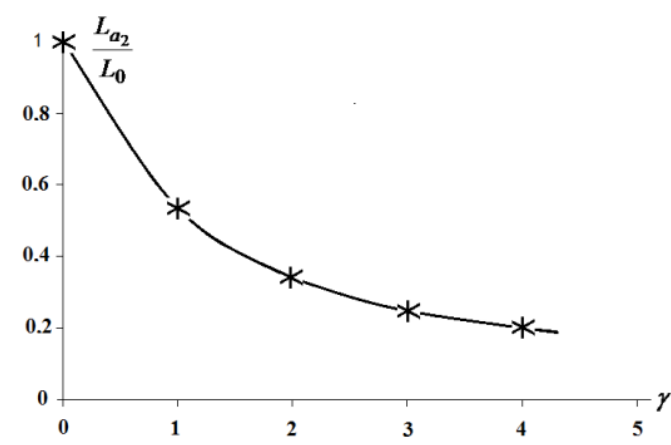

Fig. 2. Dependency graph $\frac{L_{a_{2}}}{L_{0}}=f(\gamma)$ with $\tau=0$

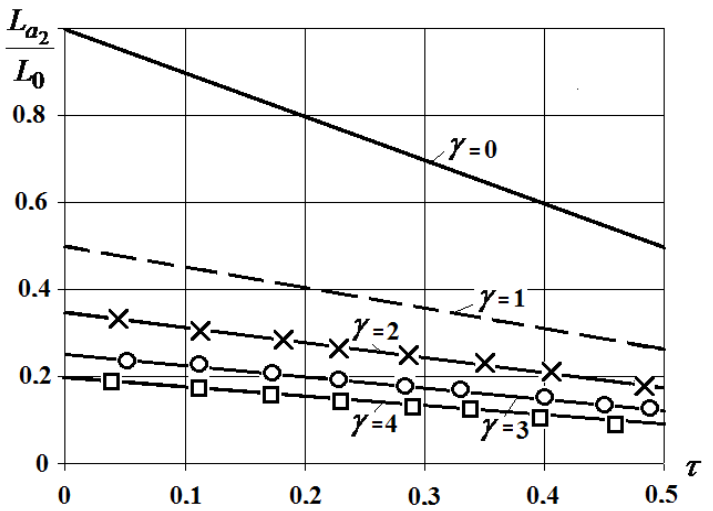

Fig. 3. Dependency graph $\frac{L_{a_{2}}}{L_{0}}=f(\tau, \gamma)$

The paper [10 (Fig. 2, 3)] presents the comparative results of the studies of simultaneous OP clarification in complete-mix aerotank, in which the elements of additional loading are evenly arranged. When constructing these graphs, the dependence (5) is used, in which the parameters $\tau$ and $\gamma$ are taken in accordance with the adopted process flow scheme of the complete-mix aerotank, namely:

$$
\begin{gathered}
\tau=\frac{T_{a} w_{a}}{L_{0}}, \quad \gamma=\frac{F_{\delta l}}{Q_{a}} K_{L}(1-A), \\
T_{a}=\frac{W_{p a}}{Q_{a}}, \quad W_{p a}=\varepsilon W_{a} .
\end{gathered}
$$

$\mathrm{F}_{\delta 1}$ is the total area of loading elements in the complete-mix aerotank with length $l$ and volume $\mathrm{W}_{\mathrm{al}}$. According to [10 (Fig. 2, 3)], only at significant values of the parameter $\tau$ and minor values of $\gamma$ one should also take into account the removal of OP due to the active sludge.
The obtained dependencies and performed calculations allow substantiating the increase in efficiency of the aerotank using the arrangement of loading elements with the attached biocenosis in the second half of its volume.

The works [7, 10] present theoretical studies and methods for calculating the parameters of biological wastewater treatment from organic pollutants (OP) in continuous-flow aeration tanks with simulatneous purification of suspended and attached biocenosis. To evaluate the efficiency of such aerotanks, let us consider the scheme of their work with the suspended and attached biocenosis when the loading elements (nozzles, screens, etc.) are evenly spaced along the entire length $l$ [10].

As a result of the theoretical studies carried out under the condition that the removal of the OP by the suspended and attached biocenosis occurs by the first-order reaction, the following dependence is obtained to determine the change in the concentration of $L_{a}$ along the aerotank $X$

$$
\begin{gathered}
L_{a}(X)=L_{0} \tilde{x}=e^{-B \bar{x}} \\
\tilde{x}=\left(A_{*}+k_{a^{*}}\right) x=B \bar{x}, \quad B=\left(A_{*}+k_{a^{*}}\right) l, \quad \bar{x}=\frac{x}{l},
\end{gathered}
$$

where

$$
\begin{gathered}
A_{*}=\frac{\lambda_{0}}{V}(1-A), \quad k_{a *}=\frac{k_{a}}{V}, \quad \lambda_{0}=\frac{F_{\delta}}{F_{a}} K_{L}, \\
k_{a}=\frac{\mu_{m a} X_{a}}{K_{m a} Y_{a}}, \quad V=\frac{Q_{a}}{F_{a}}
\end{gathered}
$$

$F_{\delta}=F_{\delta l}$ is the loading surface area (biofilm) per unit length of aerotank $l(\mathrm{~m}), K_{L}-$ coefficient of mass transfer in a liquid film $(\mathrm{m} / \mathrm{h}), A=\frac{L_{\delta}}{L_{0}}$ is the biofilm parameter determined according to the recommendations given in the papers [7,9].

At the exit of the aerotank we have

$$
\begin{gathered}
x=l, \bar{x}=1, \\
L_{a}(l)=L_{0} e^{-\tilde{l}}=L_{0} e^{-B}, \tilde{l}=B .
\end{gathered}
$$

In order to carry out further analysis and obtain comparative estimates of the influence of various factors on the clarification processes in this case, we represent the dependence (10) in the form 


$$
\frac{L_{a}(l)}{L_{0}}=e^{-\left(B_{L}+B_{a}\right)},
$$

where $B_{L}=l A_{*}, \quad B_{a}=l k_{a^{*}}$.

Thus, at $B_{L}=0$ the removal of OP in aerotanks occurs only at the expense of suspended biocenosis (active sludge), and at $B_{a}=0$ - only at the expense of the attached biocenosis (biofilm).

Based on the dependence (11), we built the calculated graphs $\frac{L_{a}(l)}{L_{0}}=f\left(B_{L}, B_{a}\right)$, presented in work [8 (Fig. 3)] and in Fig. 4

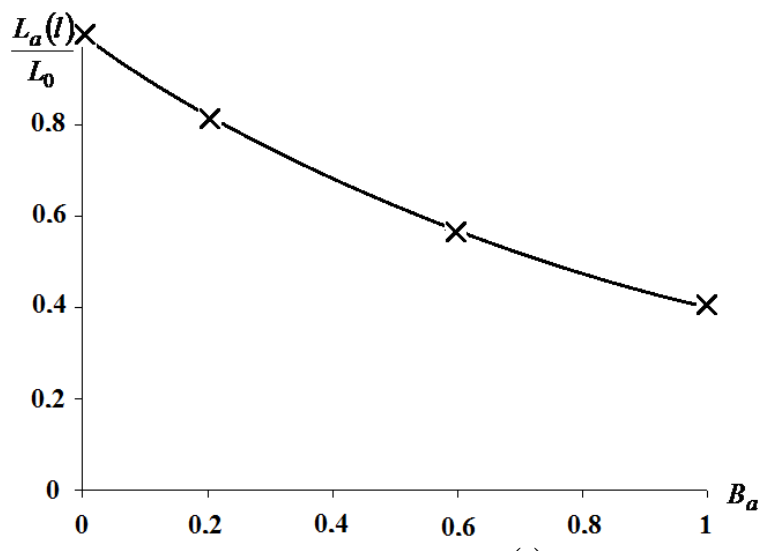

Fig. 4. Dependence graph $\frac{L_{a}(l)}{L_{0}}=f\left(B_{a}\right)$ with $B_{L}=0$

The results of the calculations presented in $[8$ (Fig. 3)] and in Fig. 4 show that the additional introduction into the aerotank of loading with the attached biocenosis (biofilm) allows to significantly improve the work of the continuous-flow aeration tank, especially with $B_{L}<1$.

The work [13] presents an experimental evaluation of the efficiency (EF) of the complete-mix aerotank due to add-on plastic screens, the results of which at $Q_{a}=110 \mathrm{ml} / \mathrm{min}, L_{0}=150 \frac{m g B O D_{5}}{l}$ are given in Table 1.

The Table 1 shows a significant increase in EF, a decrease in $L_{a}$ when using 6 screens and a gradual increase in efficiency with increasing number of screens. In this case, the total increase in efficiency is $25 \%$. As noted earlier in Fig. 2, 3 and in [10 (Fig. 2)], the intensity of the increase in efficiency is stabilized upon achievement of the minimum concentration of pollutants at the output $L_{a}$.
Table 1

Experimental EF evaluation of OP removal in aerotank

\begin{tabular}{c|c|c|c|c}
\hline Loading & $\begin{array}{c}\text { Relativ } \\
\text { e EF } \\
\text { in\% }\end{array}$ & $\begin{array}{c}\text { Total } \\
\text { EF in\% }\end{array}$ & $\begin{array}{c}\text { Intensity } \\
\text { of EF } \\
\text { in\%, }\end{array}$ & $\begin{array}{c}L_{a}, \\
\mathrm{mg} / 1 \text { at } \\
\text { the } \\
\text { output }\end{array}$ \\
\hline 0 screens & 0 & 72.50 & - & 44 \\
6 screens & 25 & 90.00 & 17.50 & 16 \\
12 screens & 50 & 95.00 & 22.50 & 8 \\
18 screens & 75 & 96.50 & 23.75 & 6 \\
24 screens & 100 & 97.50 & 25.00 & 4
\end{tabular}

\section{Findings}

The comparative calculations on the presented dependencies make it possible to estimate the intensity of increasing the clarification efficiency in aerotanks due to additional elements with attached biocenosis. The constructed models take into account the special features of the intake of organic pollutants and oxygen in a biofilm, its parameters, as well as the velocity of kinetic reactions with the simultaneous removal of organic contamination by suspended and attached biocenosis.

Implementation of the calculation methods for the proposed dependencies allows more fully and reasonably to consider the important processes of wastewater treatment, which occur with the additional involvement of the attached biocenosis. These processes significantly affect both the disposal of OP and the efficiency of aerotanks.

\section{Originality and practical value}

As part of the study described in this article, it is proposed to increase the efficiency of the aerotanks by allotting its part for additional loading with attached biocenosis. In this part there is simultaneous oxidation of organic pollutants with active sludge and biofilm. The mathematical model describing this process is presented. There are carried out calculations, performed comparative evaluation of the unit efficiency, depending on the degree of influence of the additional loading. Such an evaluation allows us to justify the rational parameters of the biological treatment unit of improved design. This means that the obtained scientific result in the form of the results of calculations based 
on the mathematical model of biological oxidation of organic pollutants by suspended and attached biocenosis, including an assessment of the influence of these components on the purification efficiency, is interesting from a theoretical point of view. From the practical point of view, the conducted researches allow to justify the use of additional loading with attached microorganisms in order to improve the quality of removal of organic pollutants in aerotanks.

\section{Conclusions}

The results obtained in the article give grounds for asserting the possibility of introducing into the actual technological process of wastewater treatment the use of attached biocenosis in aerotanks, which will allow getting effluent at the output from the facilities with a concentration of organic substances within the permissible values.

\section{LIST OF REFERENCE LINKS}

1. Водовідведення та очистка стічних вод міста. Курсове і дипломне проектування. Приклади та розрахунки : навч. посіб. / О. А. Василенко, С. М. Епоян, Г. М. Смірнова [та ін.]. - Київ : КНУБА ; Харків : ХНУБА : Ексклюзив, 2012. - 538 с.

2. Воронов, Ю. В. Водоотведение и очистка сточных вод : учебник для вузов / Ю. В. Воронов. - Москва : ACB, 2009. - $760 \mathrm{c}$.

3. ДБН В.2.5-75-2013. Каналізація. Зовнішні мережі та споруди. Основні положення проектування. Київ : Мінрегіон України, 2013.- 128 с.

4. Дослідження процесів очищення стічних вод від біогенних елементів та утилізації енергетичного потенціалу стічних вод : монографія / О. О. Грицина, М. А. Єсін, В. С. Жукова [та ін.]. - Рівне : Нац. ун-т водн. госп-ва та природокористування, 2018. - 268 с.

5. Жмур, Н. С. Технологические и биохимические процессы очистки сточных вод на сооружениях с аеротенками / Н. С. Жмур. - Москва : АКВАРОС, 2003. - 507 с.

6. Моделювання ефективності роботи станції біологічного очищення стічних вод / О. О. Шевченко, В. А. Крупко, Л. М. Клінцов, І. М. Іванова // Восточно-Европейский журнал передовых технологий. 2014. - № 5/10 (71). - С. 16-20.

7. Олійник, О. Я. Моделювання очистки стічних вод від органічних забруднень в біореакторахаеротенках зі зваженим (вільно плаваючим) і закріпленим біоценозом / О. Я. Олійник, Т. С. Айрапетян // Доповіді НАН України. - 2015. - № 5. - С. 55-60. doi: http://doi.org/10.15407/dopovidi2015.05.055

8. Олійник, О. Я. Підвищення ефективності роботи аеротенків-витискувачів за рахунок завислого і зваженого біоценозу / О. Я. Олійник, Т. С. Айрапетян // Проблеми водопостачання, водовідведення та гідравліки : наук.-техн. зб. - Київ, 2016. - Вип. 26. - С. 123-130.

9. Олійник, О. Я. Моделювання і розрахунки біологічної очистки стічних вод на краплинних біофільтрах / О. Я. Олійник, О. А. Колпакова // Екологічна безпека та природокористування : зб. наук. -техн. пр. Київ, 2014. - Вип. 16. - С. 68-86.

10. Олейник, А. Я. Повышение эффективности работы аеротенков / А. Я. Олейник, Т. С. Айрапетян // Вісн. Одес. держ. акад. буд-ва та архітектури : зб. наук. пр. - Одеса, 2015. - Вип. 59. - С. 216-224.

11. Biliaev, M. M. Modeling of biological wastewater treatment on the basis of quick-computing numerical model / M. M. Biliaev, M. V. Lemesh // Наука та прогрес транспорту. - 2018. - № 1 (73). - C. 15-23. doi: http://doi.org/10.15802/stp2018/124882

12. Biological Wastewater Treatment: Principles, Modelling and Design / M. Henze, M. C. M. van Loosdrecht, G. A. Ekama, D. Brdjanovic. - London : IWA Publishing, 2008. - 511 p.

13. Gebara, F. Activated sludge biofilm waste water treatment system / F. Gebara // Water Research. - 1999. Vol. 33. - Iss. 1. - P. 230-238. doi: https://doi.org/10.1016/s0043-1354(98)00210-3

14. Improving a compact biofilm reactor to realize efficient nitrogen removal performance: step-feed, intermittent aeration, and immobilization technique / M. Zeng, J. Hu, D. Wang [et al.] // Environmental Science and Pollution Researchю. - 2018. - Vol. 25. - Iss. 7. - P. 6240-6250. doi: https://doi.org/10.1007/s11356-017-0935-9

15. Marzec, M. Reliability of removal of selected pollutants in different technological solutions of household wastewater treatment plants / M. Marzec // Journal of Water and Land Development. - 2017. - Vol. 35. Iss. 1. - P. 141-148. doi: https://doi.org/10.1515/jwld-2017-0078 
16. Plant-wide model-based analysis of iron dosage strategies for chemical phosphorus removal in wastewater treatment systems / C. Kazadi Mbamba, E. Lindblom, X. Flores-Alsina [et al.] // Water Research. - 2019. Vol. 155. - P. 12-25. doi: https://doi.org/10.1016/j.watres.2019.01.048

17. Revilla, M. Analysis of simulation tools and optimization of the operational conditions for biofilm activated sludge industrial process / M. Revilla, B. Galán, J. R. Viguri // International Journal of Environmental Science and Technology. $\quad-\quad 2018 . \quad-\quad$ Vol. $15 . \quad-\quad$ Iss. $12 . \quad$ - $\quad$ P. $2499-2510$. doi: https://doi.org/10.1007/s13762-017-1626-2

18. Shamsutdinova, Z. R. Analysis of the aerotanks efficiency in wastewater treatment system / Z. R. Shamsutdinova, I. I. Khafizov // Proceedings of the Voronezh State University of Engi-neering Technologies. - 2016. Iss. 4. - P. 245-249. doi: https://doi.org/10.20914/2310-1202-2016-4-245-249

19. Shreve, M. J. Trace organic contaminant removal in six full-scale integrated fixed-film activated sludge (IFAS) systems treating municipal wastewater / M. J. Shreve, R. A. Brennan // Water Research. - 2019. Vol. 151. - P. 318-331. doi: https://doi.org/10.1016/j.watres.2018.12.042

20. Groundwater share quantification through flood hydrographs simulation using two temporal rainfall distributions / K. S. Balkhair, A. Masood, M. Almazroui [et al.] // Desalination and Water Treatment. - 2018. Vol. 114. - P. 109-119. doi: ttps://doi.org/10.5004/dwt.2018.22346

21. The development of simultaneous partial nitrification, ANAMOX and denitrification process in a single reactor for nitrogen removal / H. Chen, S. Liu, F. Yang, Y. Xue, T. Wang // Bioresource Technology. - 2009. Vol. 100. - Iss. 4. - P. 1548-1554. doi: https://doi.org/10.1016/j.biortech.2008.09.003

22. The transformation of nitrogen and phosphorus compounds during biological treatment at the minsk treatment plant / R. M. Markevich, M. V. Rymovskaya, I. A. Grebenchikova, E. A. Flyurik, I. P. Dziuba // Biotechnology and the Ecology of Big Cities / Edited by S. D. Varfolomeev, G. E. Zaikov, L. P. Krylova. Minsk : Nova Science Publishers, 2011. - P. 53-60.

23. Von Sperling, M. Biological wastewater treatment series. Vol. 5 : Activated sludge and aerobic biofilm reactors / M. Von Sperling. - London : IWA Publishing, 2007. - 340 p.

\title{
О. Я. ОЛІЙНИК ${ }^{1}$, Т. С. АЙРАПЕТЯН ${ }^{2 *}$, С. М. КУРГАНСЬКА ${ }^{3}$
}

\begin{abstract}
${ }^{1}$ Відділ прикладної гідродинаміки, Інститут гідромеханіки НАН України, вул. Желябова, 8/4, Київ, Україна, 03057, тел. +38 (050) 55972 89, +38 (044) 45965 10, ел. пошта Oleynik2019Al@ gmail.com, ORCID 0000-0002-9110-1709

${ }^{2 *}$ Каф «Водопостачання, водовідведення і очищення вод», Харківський національний університет міського господарства імені О. М. Бекетова, вул. Маршала Бажанова, 17, Харків, Україна, 61002, тел. +38 (057) 70733 40,

+38 (057) 70731 06, ел. пошта Tamara.Ayrapetyan@kname.edu.ua, ORCID 0000-0002-8834-5622

${ }^{3}$ Відділ прикладної гідродинаміки, Інститут гідромеханіки НАН України, вул. Желябова, 8/4, Київ, Україна, 03057 , тел. +38 (063) 91787 84, ел. пошта kurganska@ukr.net, ORCID 0000-0002-7593-6458

\section{ОЦІНКА ЕФЕКТИВНОСТІ РОБОТИ АЕРОТЕНКІВ ЗА РАХУНОК ДОДАТКОВОГО ВЛАШТУВАННЯ ЗАКРІПЛЕНОГО БІОЦЕНОЗУ}

Мета. Дослідження передбачає виконання порівняльних розрахунків для оцінки ефективності роботи аеротенків із додатковим закріпленим біоценозом (біоплівкою). Методика. Для підвищення ефективності роботи аеротенків за рахунок упровадження додаткового завантаження із закріпленим біоценозом (біоплівкою) побудовано математичні моделі, що враховують одночасне окислення органічних забруднень завислим і закріпленим біоценозом. На основі цих моделей розроблено методи розрахунку параметрів очищення. 3'ясовано вплив різних факторів на очищення в аеротенках, установлено, що інтенсивність очищення підвищується за рахунок додаткових елементів із закріпленим біоценозом. При цьому розглянуто можливі технологічні й конструктивні схеми аеротенків, коли елементи завантаження (насадки, сітки тощо) розташовані по всьому їх об'єму або більш щільно й компактно тільки на окремих ділянках. Результати. Визначені за допомогою чисельних методів параметри очищення стічних вод від органічних забруднень і побудовані графіки показують значну ефективність роботи аеротенків за рахунок упровадження додаткового завантаження із закріпленим біоценозом (біоплівкою). Виконані розрахунки впливу додаткового завантаження на ефективність роботи аеротенків-змішувачів та аеротенків-витискувачів показали, що використання іммобілізованого біоценозу дозволяє підвищити якість видалення органічних забруднень у 2-5 разів. 
Наукова новизна. Науково обгрунтовано вплив різних факторів на очищення стічних вод в аеротенках, ефективність якого підвищується за рахунок додаткових елементів із закріпленим біоценозом. Практична значимість. У разі впровадження результатів досліджень на підприємствах з очистки стічних вод може бути значно підвищена якість видалення органічних забруднень біологічними методами. Реалізація методів розрахунку за запропонованими залежностями дозволяє більш повно й обгрунтовано врахувати важливі процеси, які значно впливають на утилізацію органічних забруднень та ефективність роботи аеротенків із додатковим залученням для очищення стічних вод закріпленого біоценозу.

Ключові слова: аеротенки-реактори; закріплений біоценоз (біомаса); біоплівка; активний мул; реакції очищення

\section{А. Я. ОЛЕЙНИК ${ }^{1}$, Т. С. АЙРАПЕТЯН ${ }^{2 *}$, С. Н. КУРГАНСКАЯ ${ }^{3}$}

${ }^{1}$ Отдел прикладной гидродинамики, Институт гидромеханики НАН Украины, ул. Желябова, 8/4, Киев, Украина, 03057 , тел. +38 (050) 55972 89, +38 (044) 45965 10, эл. почта Oleynik2019Al@ gmail.com, ORCID 0000-0002-9110-1709

${ }^{2 *}$ Каф. «Водоснабжение, водоотведение и очистка вод», Харьковский национальный университет городского хозяйства имени А. Н. Бекетова, ул. Маршала Бажанова, 17, Харьков, Украина, 61002, тел. +38 (057) 7073340 ,

+38 (057) 70731 06, эл. почта Tamara.Ayrapetyan@ kname.edu.ua, ORCID 0000-0002-8834-5622

${ }^{3}$ Отдел прикладной гидродинамики, Институт гидромеханики НАН Украины, ул. Желябова, 8/4, Киев, Украина, 03057 , тел. +38 (063) 91787 84, эл. почта kurganska@ukr.net, ORCID 0000-0002-7593-6458

\section{ОЦЕНКА ЭФФЕКТИВНОСТИ РАБОТЫ АЭРОТЕНКОВ ЗА СЧЕТ ДОПОЛНИТЕЛЬНОГО УСТРОЙСТВА ПРИКРЕПЛЕННОГО БИОЦЕНОЗА}

Цель. Исследование предусматривает выполнение сравнительных расчетов для оценки эффективности работы аэротенков с дополнительным прикрепленным биоценозом (биопленкой). Методика. Для повышения эффективности работы аэротенков за счет внедрения дополнительной загрузки с прикрепленным биоценозом (биопленкой) построены математические модели, которые учитывают одновременное окисление органических загрязнений взвешенным и прикрепленным биоценозом. На основе этих моделей разработаны методы расчета параметров очистки. Определено влияние различных факторов на очистку в аэротенках, установлено, что интенсивность очистки повышается за счет дополнительных элементов с прикрепленным биоценозом. При этом рассмотрены возможные технологические и конструктивные схемы аэротенков, когда элементы загрузки (насадки, сетки и т. п.) расположены по всему их объему или более плотно и компактно только на отдельных участках. Результаты. Определенные с помощью численных методов параметры очистки сточных вод от органических загрязнений и построенные графики показывают значительную эффективность работы аэротенков за счет внедрения дополнительной загрузки с прикрепленным биоценозом (биопленкой). Выполненные расчеты влияния дополнительной загрузки на эффективность работы аэротенков-смесителей и аэротенков-вытеснителей показали, что использование иммобилизованного биоценоза позволяет повысить качество удаления органических загрязнений в 2-5 раз. Научная новизна. Научно обосновано влияние различных факторов на очистку сточных вод в аэротенках, эффективность которой повышается за счет дополнительных элементов с прикрепленным биоценозом. Практическая значимость. При внедрении результатов исследований на предприятиях по очистке сточных вод может быть значительно повышено качество удаления органических загрязнений биологическими методами. Реализация методов расчета по предложенным зависимостям позволяет более полно и обоснованно учесть важные процессы, которые значительно влияют на утилизацию органических загрязнений и эффективность работы аэротенков с дополнительным привлечением для очистки сточных вод прикрепленного биоценоза.

Ключевые слова: аэротенки-реакторы; прикрепленный биоценоз (биомасса); биопленка; активный ил; реакции очистки 


\section{REFERENCES}

1. Vasylenko, O. A., Epoian, C. M., Smirnova, H. M., Korinko, I. V., Vasylenko, L. O., \& Airapetian, T. S. (2012). Vodovidvedennia ta ochystka stichnykh vod mista. Kursove i dyplomne proektuvannia. Pryklady ta rozrakhunky: Navchalnyi posibnyk. Kyiv: KNUBA; Kharkiv: KhNUBA; Ekskliuzyv. (in Ukrainian)

2. Voronov, Y. V. (2009). Vodootvedenie i ochistka stochnykh vod: uchebnik dlya vuzov. Moskow: ASV. (in Russian)

3. Kanalizatsiia. Zovnishni merezhi ta sporudy. Osnovni polozhennia proektuvannia, 128 DBN V.2.5-75-2013 (2013). (in Ukrainian)

4. Hrytsyna, O. O., Yesin, M. A., Zhukova, V. S., Bliashyna, M. V., \& Voloshchuk, V. A. (2018). Doslidzhennia protsesiv ochyshchennia stichnykh vod vid biohennykh elementiv ta utylizatsii enerhetychnoho potentsialu stichnykh vod: Monohrafiia. Rivne: Natsionalnyi universytet vodnoho hospodarstva ta pryrodokorystuvannia. (in Ukrainian)

5. Zhmur, N. S. (2003). Tekhnologicheskie i biokhimicheskie protsessy ochistki stochnykh vod na sooruzheniyakh s aerotenkami. Moskow: AKVAROS. (in Russian)

6. Shevchenko, O. O., Krupko, V. A., Klintsov, L. M., \& Ivanova, I. M. (2014). Modeliuvannia efektyvnosti roboty stantsii biolohichnoho ochyshchennia stichnykh vod. Eastern-European Journal of Enterprise Technologies, 5/10(71), 16-20. (in Ukrainian)

7. Oleynik, A. Y., \& Airapetyan, T. S. (2015). The modeling of the clearance of waste waters from organic pollutions in bioreactors-aerotanks with suspended (free flow) and fixed biocenoses. Reports of the National Academy of the Sciences of the Ukraine, 5, 55-60. doi: http://doi.org/10.15407/dopovidi2015.05.055 (in Ukrainian)

8. Oleynik, A. Y., \& Airapetyan, T. S. (2016). Pidvyshchennia efektyvnosti roboty aerotenkiv-vytyskuvachiv za rakhunok zavysloho i zvazhenoho biotsenozu. Problemy vodopostachannia, vodovidvedennia ta hidravliky, 26, 123-130. (in Ukrainian)

9. Oleynik, A. Y., \& Kolpakova, O. A. (2014). Modelling and calculation of bioiligical wastewater treatment to trickling biofilters. Environmental safety and natural resources, 16, 68-86. (in Ukrainian)

10. Oleynik, A. Y., \& Ayrapetyan, T. S. (2015). Povyshenie effektivnosti raboty aerotenkov. Bulletin of Odessa state academy of civil engineering and architecture: collection of scientific works, 59, 216-224. (in Russian)

11. Biliaiev, M. M., \& Lemesh, M. V. (2018). Modeling of biological wastewater treatment on the basis of quickcomputing numerical model. Science and Transport Progress, 1(73), 15-23. doi: http://doi.org/10.15802/stp2018/124882 (in English)

12. Henze, M., Van Loosdrecht, M. C. M., Ekama, G. A., \& Brdjanovic, D. (2008). Biological Wastewater Treatment: Principles, Modelling and Design. London: IWA Publishing. (in English)

13. Gebara, F. (1999). Activated sludge biofilm wastewater treatment system. Water Research, 33(1), $230-238$. doi: https://doi.org/10.1016/s0043-1354(98)00210-3 (in English)

14. Zeng, M., Hu, J., Wang, D., Wang, H., Wang, Y., Wu, N., ... Wang, C. (2017). Improving a compact biofilm reactor to realize efficient nitrogen removal performance: step-feed, intermittent aeration, and immobilization technique. Environmental Science and Pollution Research, 25(7), 6240-6250. doi: https://doi.org/10.1007/s11356-017-0935-9 (in English)

15. Marzec, M. (2017). Reliability of removal of selected pollutants in different technological solutions of household wastewater treatment plants. Journal of Water and Land Development, 35(1), 141-148. doi: https://doi.org/10.1515/jwld-2017-0078 (in English)

16. Kazadi Mbamba, C., Lindblom, E., Flores-Alsina, X., Tait, S., Anderson, S., Saagi, R., ... Jeppsson, U. (2019). Plant-wide model-based analysis of iron dosage strategies for chemical phosphorus removal in wastewater treatment systems. Water Research, 155, 12-25. doi: https://doi.org/10.1016/j.watres.2019.01.048 (in English)

17. Revilla, M., Galán, B., \& Viguri, J. R. (2017). Analysis of simulation tools and optimization of the operational conditions for biofilm activated sludge industrial process. International Journal of Environmental Science and Technology, 15(12), 2499-2510. doi: https://doi.org/10.1007/s13762-017-1626-2 (in English)

18. Shamsutdinova, Z. R., \& Khafizov, I. I. (2016). Analysis of the aerotanks efficiency in wastewater treatment system. Proceedings of the Voronezh State University of Engineering Technologies, 4, 245-249. doi: https://doi.org/10.20914/2310-1202-2016-4-245-249 (in English) 
19. Shreve, M. J., \& Brennan, R. A. (2019). Trace organic contaminant removal in six full-scale integrated fixedfilm activated sludge (IFAS) systems treating municipal wastewater. Water Research, 151, 318-331. doi: https://doi.org/10.1016/j.watres.2018.12.042 (in English)

20. Balkhair, K. S., Masood, A., Almazroui, M., Rahman, K. U., Bamaga, O. A., Kamis, A. S., ... Hesham, K. (2018). Groundwater share quantification through flood hydrographs simulation using two temporal rainfall distributions. Desalination and Water Treatment, 114, 109-119. doi: https://doi.org/10.5004/dwt.2018.22346 (in English)

21. Chen, H., Liu, S., Yang, F., Xue, Y., \& Wang, T. (2009). The development of simultaneous partial nitrification, ANAMMOX and denitrification (SNAD) process in a single reactor for nitrogen removal. Bioresource Technology, 100(4), 1548-1554. doi: https://doi.org/10.1016/j.biortech.2008.09.003 (in English)

22. Markevich, R. M., Rymovskaya, M. V., Grebenchikova, I. A., Flyurik, E. A., \& Dziuba, I. P. (2011). The transformation of nitrogen and phosphorus compounds during biological treatment at the minsk treatment plant. In S. D. Varfolomeev, G. E. Zaikov, L. P. Krylova (Eds.), Biotechnology and the Ecology of Big Cities. Minsk: Nova Science Publishers. (in English)

23. Von Sperling, M. (2007). Biological wastewater treatment series. Vol. 5: Activated sludge and aerobic biofilm reactors. London: IWA Publishing. (in English)

Received: March 22, 2019

Accepted: July 15, 2019 